\title{
Information Systems Success in the Public Sector: Stakeholders' Perspectives and Emerging Alignment Model
}

\author{
Ivana Elpez and Dieter Fink \\ Edith Cowan University, Perth, Australia
}

\author{
d.fink@ecu.edu.au
}

\begin{abstract}
There have been many attempts to define Information Systems (IS) success but they have mostly been in the private sector. This paper reviews existing IS success models and then takes into account stakeholders as well as public sector perspectives in conducting qualitative case studies of 3 major Western Australian government agencies. Findings of the study identified key IS success variables relevant to the public sector and characteristics that distinguish the public from the private sector. By aligning success variables with these characteristics, it was possible to conceptualise an early theoretical IS success model for the sector.
\end{abstract}

Keywords: IS success, IS success models, IS in public sector, IS case studies, Public sector

\section{Introduction}

It is commonly accepted that Information Technology (IT) has become a tool with which to produce accurate, reliable and timely information through the development of Information Systems (IS). For an IS to be judged successful, however, it has to satisfy additional criteria in today's competitive world. For example, at a broad level, it is expected that it becomes a key component in achieving the organisation's mission (Drury \& Farhoomand, 1998 referenced by Garson, 1999) and more narrowly, improve productivity and facilitate service delivery (Brown, 1999 cited by Garson, 1999). Even a cursory examination of the IS literature reveals that organisations have utilised numerous surrogate measures for IS success (see Hwang, Windsor, \& Pryor, 2000).

What is also evident is that IS Success studies have been conducted mostly in the private sector (Specht, 1999 cited by Garson, 1999) while research into IS success within the public sector has been greatly neglected (Seneviratne, 1999). Overall, it has been concluded that little progress has been made in how to achieve IS success within the public sector (Brown, 1999 cited by Garson, 1999). Yet IS are critical to increase effectiveness and efficiency in the delivery of public ser-

Material published as part of this publication, either on-line or in print, is copyrighted by the Informing Science Institute. Permission to make digital or paper copy of part or all of these works for personal or classroom use is granted without fee provided that the copies are not made or distributed for profit or commercial advantage AND that copies 1 ) bear this notice in full and 2) give the full citation on the first page. It is permissible to abstract these works so long as credit is given. To copy in all other cases or to republish or to post on a server or to redistribute to lists requires specific permission and payment of a fee. Contact Publisher@InformingScience.org to request redistribution permission. vices, the management of critical information sources for decision making affecting the population, and formulation of public policy (Lynn, 1999 cited by Garson, 1999). The spectacular growth of public investment in IT further reflects an enormous potential for improving the performance of public organisations (Lynn 1998 cited by Garson, 1999). As such, understanding what contributes to IS success is of great im- 
portance and value to public sector agencies (Seneviratne, 1999).

The objective of this study was to establish what IS success is within the Western Australian (WA) government sector. A stakeholder perspective was adopted since it was argued that success of an IS project is what stakeholders perceive it to be. To achieve this outcome, the views on how the public sector differs from the private sector were also captured. This would lead to an early model of IS success within the public sector in which key IS success variables would be aligned with public sector characteristics. In this way the study seeks to add to the current lack of research into IS success in the public sector thereby providing new insights to both the researcher and IS professional working in the sector.

\section{Background Literature}

When reviewing background literature, three key perspectives were encountered; they are outlined below and provided the basis for designing our research.

\section{The IS Success Model Perspective}

Much of the work done in IS success has its origin in the well-known DeLone and McLean (D\&M) IS Success Model (DeLone \& McLean, 1992). This model provided a comprehensive taxonomy on IS success based on the analysis of more then 180 studies on IS success and identified over 100 IS success measures during the analysis. It established that System Quality, Information Quality, Use, User Satisfaction, Individual and Organisational Impact were the most distinct elements of the IS success equation. In a later work, the authors confirmed the original taxonomy and their conclusion, namely that IS success was "a multidimensional and interdependent construct” (DeLone \& McLean, 2003, p. 12).

Seddon (1997) proposed a respecified and extended version of the original D\&M IS Success model with the purpose of clarifying confusion caused by the integration of process and casual explanation of IS success measures. According to Seddon (1997), DeLone and McLean (1992) "tried to do too much in their model, and as a result, it is both confusing and misspecified" (p. 240). Seddon used literature on IS success to theoretically evaluate IS success measures and proposed the extended IS Success model. His model focused on measures of information and system quality and net benefits of IS use. As a result, IS success variables were: System Quality, Information Quality, Perceived Usefulness, User Satisfaction, Net Benefits to Individuals, Net Benefits to Organisations and Net Benefits to Society.

An alternative model is the 3-D Model of IS success, introduced by Ballantine Bonner, and Levy (1998) as an attempt to restructure the original D\&M model. They identified the need to restructure existing relationships between identified dimensions, identified the lack of accountability for the systemic nature of organisations and the need for critical awareness of identified dimensions and their limitations. The name of the 3-D Model of IS success comes from the three IS dimensions included in the model: Development, Deployment and Delivery. Ballantine et al. (1998) identified factors for each level in the model that determine the quality of the IS. Those factors are either endogenous or exogenous. Exogenous factors include those that cannot be predicted, such as economic and political factors, while endogenous factors, on the other hand, include items that are controllable.

More recently, Hwang et al. (2000) claimed that success of an IS project is directly related to environmental factors related to the organisation, users, IS operations, IS development, IS and external environment. They influence Use, Satisfaction, and the Individual and Organisational Impact of IS. The five environmental variables provided in their System Success Model come from the Ives et al (1980) model which included three process variables, which have been replaced by four success measures from the DeLone and McLean IS Success Model of 1992. 


\section{The Stakeholder Perspective}

From a 'stakeholder' perspective, each stakeholder is in the position to view the project outcome from various perspectives and arrive at different conclusions. To obtain a comprehensive perspective on IS success these views have to be considered. In the IS discipline, relevant stakeholders can readily be identified as those that will ultimately use the system (end-users) and those charged with delivering those systems (IS professionals). From an end-user perspective, high usability of the system is logically linked to IS success. "If users cannot use the system effectively and efficiently it cannot be deemed to be a success" (Fisher, 2001, p. 25). Several factors have greatly contributed to the usability of an IS; they were identified by Fisher (2001) as shown in Table 1.

Table 1: Variables for IS usability

\begin{tabular}{|l|}
\hline User expectations of a system \\
\hline Task-technology fit \\
Understanding the user's perspective. The system reflects the \\
cognitive style and mental model of the users \\
Meeting user expectations or perceptions of the system \\
\hline System usability \\
\hline Quality and effectiveness of the interface design \\
Quality and effectiveness of user documentation and infor- \\
mation \\
Ease of use \\
\hline User acceptance and ownership of a system \\
Level of user involvement in the development process \\
Participation in the development leading to greater commit- \\
ment \\
The extent of user involvement and participation \\
The quality of user-developer communication \\
The quality of the system and system reliability \\
\hline
\end{tabular}

As shown in Table 1, the user's expectations of a system is important in gaining an understanding of the user's perspective on IS success. Users with realistic expectations of an IS have higher levels of satisfaction and are more likely to engage in the use of the IS when compared to users with unrealistic expectations (Ginzberg, 1981; Szajna \& Scamell, 1993). System usability refers to "the degree to which a person believes that using a particular system would enhance his or her job performance” (Davis, 1989, p. 320). In this category, the quality and effectiveness of the user interface, documentation of information as well as ease of use are indicators of IS success. Ease of use has been defined as "the degree to which a person believes that using a particular system would be free from effort” (Davis, 1989, p. 320). It contributes significantly to user satisfaction (Seddon \& Kiew, 1996). User acceptance and ownership of the system can be defined as "a subjective psychological state reflecting the importance and personal relevance of a system to the user” (Barki \& Hartwick, 1989, p. 53). This can be refined further into user participation which is "a set of behaviors or activities performed by users in the system development process" (Barki \& 
Hartwick, 1989, p. 53). Both user involvement and participation have been linked to the success of an IS project (Hwang \& Thorn, 1999; Kappleman \& McLean, 1991; Saleem, 1996).

Besides satisfying end-users, IS also have to receive senior management's commitment and support (Bloom, 1996). However, this stakeholder group has its own perspectives on what makes a successful IS. A study by Adelakun and Jennex (2002) revealed that IT executives, CIO's and IS managers assess success of an IS project by focusing on costs, savings, user satisfaction, value to the organisation and how well the IS interacts within the organisational infrastructure. These perceptions have been ranked in a recent study by CIO (2003) in which 118 executives participated. Internal customer/user satisfaction was considered one of the top three measures for determining the value and success of an IS project by $78 \%$ of participants. Staying at or under budget was the second most popular determining factor of IS project success (57\% of participating executives), followed by external customer satisfaction, employee productivity, improvements in competitive advantage, system uptime, organisational and IT department productivity, service level agreements and generating revenue.

Project managers are those involved in developing and implementing IS. It has been found that they are expected to reconcile the expectations of end-users and those of senior management as outlined above. They are expected to "see the big picture...be aware of the results expected....and look for long term benefits” (Shenhar, Levy, Dvir, 1997). For project managers, managing user expectations within the IS field has become a critical factor for delivering successful IS projects (Staples, Wong, \& Seddon, 2002). However, Wateridge (1998) found that project managers, although being aware of the importance of meeting user requirements, were focusing on time and budget more than on long term criteria such as delivering a system users are happy with. The reason for the emphasis on short term criteria is linked to ongoing appraisals by project manager's superiors on their ability to deliver projects within a defined time period and budget (Wateridge, 1998). This was confirmed in a recent study which found that IS success from a project management perspective was mainly associated with items such as organisational fit and business performance, cost, time and quality components (White \& Fortune, 2002).

\section{The Public Sector Perspective}

The term public sector in Australia refers to "enterprises which the Commonwealth Government, State/Territory and local governments, separately or jointly have control over. It includes local government authorities and all government departments, agencies and authorities created by, or reporting to, the Commonwealth Parliament and State parliaments. It also includes public trading enterprises such as Australia Post” (Australian Statistics, 1998). The sector has a unique purpose since "government serves all citizens through the exercise of its powers, authorities and roles, including those who are direct recipients of its services. Government therefore governs in the public interest, a role which is unique to government” (Crawford, 1996, p. 5).

Although making profit and maximising shareholder value is not the main objective of public sector agencies nor do they depend upon outperforming its competitors (DeLoof, 1996), the accountability of an IS project team within the public sector is often much wider than in the private sector (Briner, Hastings, Geddes, 1996). Furthermore, changes within the stakeholders group can create much organisational turbulence concerning political, legal, public, financial, managerial and professional issues. Public sector organisations are therefore strongly political and institutionalised (Dowse, 2003). Organisational turbulence, for example, can be very high within an election period (Campbell, 2003). As a result, CIO's and IT staff members can find themselves working for two different governments in quick succession who dislike and distrust each other and have a different attitude towards the importance of IS within the agency. As a result, a change in stakeholders of an IS project has a direct flow on effect on 'success' attainment. 
Campbell (2003) looked at financial flexibility within the public sector and concluded, somewhat paradoxical to the above, that government agencies don't have financial flexibility for quick changes like private sector organisations do. This is mainly due to budgets being planned at least a year in advance yet systems may have to respond in the short term as a result of a ministerial request. Within the Australian public sector, accountability for decision making in most cases lies with the government and its ministers (Williams, 1998). Having to deal with the requirements of legislature as well as ministerial expectations (for example a system may have to change 'overnight') adds to the complexity of system delivery and hence to the achievement of IS success.

Procurement policies are critical in most government agencies and typically require that IS within an agency need to deliver value for money, be very efficient, innovative, responsive, customer focused and provide a high quality service at optimal cost to taxpayers (Marriott, 2002). IT departments within the public sector operate with very tight budgets and decisions at every step must be justified. As Marriott (2002) states, "it is imperative that public-sector bodies are demonstrably open and fair. In addition, senior public servants need to constantly ask themselves what their decision would look like if they had to defend it to their parliamentary public-expenditure scrutiny committee” (p. 1).

Flowers (1996) believes that delivering successful IS projects within the public sector is associated with situationally specific constraints when compared to the private sector. Those constraints are outlined in Table 2 and include the politics surrounding the creation and operation of the IS, highly bureaucratic decision making processes, management, technology led, uniqueness and cost.

\section{Table 2: Typical Government IS Characteristics}

\begin{tabular}{|l|l|}
\hline \multicolumn{1}{|c|}{ Factor } & \multicolumn{1}{c|}{ Typical Government IS Development } \\
\hline Politics & $\begin{array}{l}\text { Priorities may be refocused: for instance as a result of } \\
\text { changes in government policy. Impositions of external } \\
\text { deadlines: primarily for political reasons }\end{array}$ \\
\hline Decision making & $\begin{array}{l}\text { Highly bureaucratic decision-making processes. High } \\
\text { level of public interests and oversight }\end{array}$ \\
\hline Management & Short-term tenures of managers overseeing projects \\
\hline Lead from & Technology led \\
\hline Uniqueness & Custom systems rather than packaged preferred \\
\hline Cost & Low-cost solutions not sought \\
\hline
\end{tabular}

(Adapted from Al-Wohaibi, Masoud, \& Edwards, 2002, p. 6)

\section{Research Design}

The study adopted the stakeholder approach in order to capture the opinions of those involved with IS in the Western Australian public sector. The approach conforms with Seddon's (1997) view, namely that IS success can be defined as "a measure of the degree to which the person evaluating the system believes that the stakeholder in whose interest the evaluation is being made is better off” (p. 246). Stakeholders are in a position to view the IS from various perspectives (Belassi \& Tukel, 1996). As such, end-users, project managers, project leaders, project sponsors, IT managers and CIO's were interviewed. 
Given the nature of this research study (i.e. the subjective meaning of 'IS success' as perceived by the participating stakeholders), the qualitative research method was considered as more appropriate than the quantitative research method. According to Myers (1997), trends within the IS research field show that there has been a general shift away from technological issues towards managerial and organisational issues, thus increasing the application of qualitative research methods. Hammersley (1992, cited in Travers, 2001) suggests that qualitative data is reliable because it captures the issue from the point of view of the research participants rather than from the view of the researcher. The case study research method was chosen as the appropriate qualitative research method. This method is particularly well suited to research within the IS field, as the objects of the study are linked to Information Systems within organisations (Myers, 1997).

The study covered three large IS projects developed and implemented within three Western Australian government agencies. When conducting qualitative case studies it is recommended that between 20 and 40 participants are part of in-depth interviews (Walker, 1985). Thus, 21 participants from the three government agencies were chosen who were either part of the development processes of IS or end-users of that IS depending on their availability, accessibility and the willingness to participate. Semi-structured in-depth interviews were conducted to identify what participants of the study perceived IS success within the Western Australian government sector to be. As such, the interviews followed a specific and focused agenda in alignment with the research objectives and to ensure that similar type of data was collected from participants (Holloway, 1997).

The interview agenda was pre-tested before the data collection phase by three participants who were not part of the study for reliability purposes (Yin, 2003). The interview guide consisted of three distinct parts, namely background information about the participant and the IS project being used, importance of identified IS success variables and the differences between the private and public sector within an IS context.

\section{Findings and Discussion}

\section{Background Data}

The purpose of the Case Study 1 IS project was to implement a new Document Management System and enable staff members to control, organise, access and disseminate corporate information. A team consisting of a project sponsor, project manager, project leader, two business analysts, expert programmer and programmer analyst was put together to implement and customise a common off-the-shelf records/document management package. The package was subject to several modifications and took one year and three months to implement. Participants of this case study included the project sponsor, project manager, business analyst, two end-users and one project team member.

The purpose of the Case Study 2 IS project was to upgrade the existing IT systems of electoral offices. A new computer image was created and installed on all machines. A computer image, as explained by the project manager of the Case Study 2 IS project, is "a collection of software on a computer consisting of the operating system and all of its software and drivers". The main scope of the project was the conversion of the email system to bring the electoral office email systems in line with the Ministerial offices. A team consisting of a project sponsor, project manager, project leader, business consultant and three IT support officers was put together to complete the project. Participants of this case study included the project sponsor, business consultant, IT support officer and three end-users.

The purpose of the Case Study 3 IS project was to amalgamate previously old and separate systems within the participating agency into one. Due to confidentiality reasons the main function of 
this IS cannot be stated as it would reveal the agency the IS was developed at. Nevertheless, the cost of the project was at around \$13 million and the IS was subsequently sold to one interstate jurisdiction. Participants of this case study included one project manager, one business analyst, one analyst programmer and three end-users of the IS.

\section{IS Success Factors}

An integrated account of findings is provided in Table 3. Importance ratings by participants have been used to rank IS success variables. The most important variables are highlighted in bold as explained below.

Table 3: IS Success Variables

\begin{tabular}{|c|c|c|c|}
\hline Rk & Case Study 1 & Case Study 2 & Case Study 3 \\
\hline 1 & Meeting user requirements & Meeting user requirements & $\begin{array}{l}\text { Meeting user requirements } \\
\text { Information Quality } \\
\text { Use }\end{array}$ \\
\hline 2 & $\begin{array}{l}\text { System usability and } \\
\text { performance }\end{array}$ & $\begin{array}{l}\text { Information Quality } \\
\text { Use }\end{array}$ & $\begin{array}{l}\text { System Quality } \\
\text { User participation and in- } \\
\text { volvement } \\
\text { System usability and per- } \\
\text { formance } \\
\text { User acceptance and IS } \\
\text { ownership }\end{array}$ \\
\hline 3 & $\begin{array}{l}\text { User acceptance and IS } \\
\text { ownership }\end{array}$ & $\begin{array}{l}\text { Interaction with rest of IT } \\
\text { infrastructure }\end{array}$ & $\begin{array}{l}\text { Interaction with rest of IT } \\
\text { infrastructure }\end{array}$ \\
\hline 4 & $\begin{array}{l}\text { User participation and } \\
\text { involvement } \\
\text { Interaction with rest of IT } \\
\text { infrastructure }\end{array}$ & $\begin{array}{l}\text { Improvements in employee } \\
\text { productivity }\end{array}$ & $\begin{array}{l}\text { Improvements in employee } \\
\text { productivity } \\
\text { Improvements in business per- } \\
\text { formance }\end{array}$ \\
\hline 5 & Information quality & $\begin{array}{l}\text { Satisfying user expectations } \\
\text { System quality }\end{array}$ & Satisfying user expectations \\
\hline 6 & $\begin{array}{l}\text { System quality } \\
\text { Use }\end{array}$ & $\begin{array}{l}\text { User participation and } \\
\text { involvement }\end{array}$ & Meeting budgeted criteria \\
\hline 7 & $\begin{array}{l}\text { Improving business } \\
\text { performance }\end{array}$ & $\begin{array}{l}\text { System usability and } \\
\text { performance }\end{array}$ & \\
\hline 8 & Satisfying user expectations & Meeting budgeted criteria & \\
\hline 9 & Meeting budgeted criteria & $\begin{array}{l}\text { User acceptance and IS } \\
\text { ownership }\end{array}$ & \\
\hline 10 & $\begin{array}{l}\text { Improvements in employee } \\
\text { productivity }\end{array}$ & $\begin{array}{l}\text { Improving business } \\
\text { performance }\end{array}$ & \\
\hline
\end{tabular}

When examining items ranked in the top three levels, it can be observed that meeting user requirements was the only variable for all three case studies and it was in first position. Those ranked twice in the top three rankings in two case studies were system usability and performance (ranked second, twice), information quality and use (both ranked first and second), user acceptance and IS ownership (ranked second and third), interactions with the rest of IT infrastructure (ranked third, twice).

Meeting user requirements has long been considered as a significant indicator of IS success (e.g. Wateridge, 1998) and this study again provides evidence for this. Comments were along the line of “a system that doesn't meet user requirements won't be used by users”, expressed in Case 
Study 3 by Participant 3 (CS3 - P3). Statements such as "if you don't meet user requirements they won't be happy and ultimately won't use the system” (CS1 - P1) and "no matter how wonderful it is if people don't use it it will fail” (CS1 - P1) exemplified general views. Participants also claimed that "in the end we are trying to provide a service to those people and if we don't keep them happy we haven’t done the job” (CS2 - P2). "If you don't meet the requirements what is the purpose of the project?” (CS2 - P1) one participant asked. The participant further expanded on the response by highlighting that meeting user requirements was essentially achieving the purpose of the project. "User requirements represent the business itself. If you are not meeting that you are not achieving the goal” (CS3 - P1).

Consistency in ranking was found between the views held by Case Study 1 and Case Study 3 participants in terms of the second most critical IS success variable, that of system usability and performance. As indicated by Davis (1989) system usability and performance are a large part of "the degree to which a person believes that using a particular system would enhance his or her job performance” (p.320). It was stated that "A system has to be fit for a purpose at the level of usability and quality, which is required to achieve the objectives." (CS1 - P2) Participants explained that unless usability and performance benchmarks are met users simply won't use the IS. As stated by CS3 - P6: "Once performance is not good enough, users start being not happy and kick up the sting because of it."

As seen in Table 3, case Study 3 participants placed use as one of the most critical IS success variables together with meeting user requirements. The comment below made by a participant summarises the general perceptions towards the 'use' IS success variable. CS3 - P4: "We use it constantly and it is an indication of success." CS3 - P5: "Otherwise it is just a waste of time and money and effort." Expanding on the comment, the participant associated use of an IS with information quality, which was another IS success variable receiving high importance ratings by participants. Case Study 3 participants placed information quality in the same category as meeting user requirements and use of the IS for achieving success while participants in Case Study 2 perceived information quality as the second most critical IS success variable. As one participant explained, "members of Parliament are expected to get up and be $100 \%$ accurate on what they are talking about. The information has to be $100 \%$ accurate" (CS2 - P4).

For user acceptance and ownership participants claimed that "users have to accept it and if they don't you go to the same old story. They won't use it and they'll find ways of sabotaging it or making sure that the thing is not successful" (CS1 -P1). As such, participants promoted user acceptance and IS ownership as mechanisms for achieving voluntary IS use by end-uses. For interaction with rest of IT infrastructure, participants argued that within the West Australian government sector most systems accept and process data from other agencies and as such all systems needed to integrate.

\section{Public Sector Characteristics}

In terms of the difference between the public and the private sector within an IS context the majority of participants (16/21) claimed that the two sectors are uniquely identifiable. The key differences were accountability, expenditure control and taking a long-term perspective. Theses are reflected in the comments made by participants, examples of which are reproduced below.

Accountability

- "There is not much difference except the government uses taxpayers money and is more accountable” (CS3 - P2) 
- "The government sector is more accountable for everything including the process of evaluation, what is being purchased and budgets are not as flexible. Selection process of employees and getting skilled people is also different.” (CS1 - P4)

Expenditure control

- "Working environments are different, there tends to be greater scrutiny on public sector organisations in terms of expenditure. Investors certainly do scrutinise private sector expenditure but not to the same extent. If you have a really big public sector project that fails then it is all over newspapers.” (CS1 - P1)

- "Money and time are more important in the private sector. The government wants things to be on time and budget but can always find little bit of extra money." (CS3 - P5)

- "The government has access to more money. If it is a critical project like this one the government will provide lots of money for it. In smaller private sector organisations there is a greater emphasis on costs, even with bigger organisations although they can afford to go for the latest." (CS3 - P6)

Long-tem perspective

- "The need for good, reliable and comprehensive information and not, I guess, so much cost driven when compared to the private sector where the IS might be designed to reduce and cut costs. Plus lots of agencies are providing services that private sector wouldn't provide. Services that are based on information needs.” (CS1 - P8)

- "From a general perspective, my general understanding would be that they [private sector] would be more focused on productivity improvements and financial benefits whereas the public sector is more focused on customer service and quality of the system that they put so that they are able to last for a long time.” (CS3 - P1)

- "With the private sector tenders are put out. Major emphasis is costing and time where cost and time within the government are not as emphasised.” (CS2 - P2)

Although the majority of participants claimed that the differences between the public and the private sectors impact on the success of an IS project, five participants (5 out of 21) disagreed. According to these participants, the criteria on whether a project is successful or not is not related to whether the project is being undertaken within the public or the private sector. Participants claimed that the underlining reasons for success or failure would be the same regardless of whether the IS project is completed within the public or the private sector. Four out of six participants were previously employed within the private sector and drew upon their experiences while commenting on this item. Participants stated the following:

- "I don’t think that there is a difference because any IS project is governed by the same needs, dollars and usability.” (CS2 - P4)

- 'It shouldn’t differ at all. The government should be just as efficient as the private sector." (CS2 - P5)

- "I don't believe there is any, not even in the accountability aspect." (CS2 - P6).

\section{Emerging Model}

From the study's findings it is possible to provide a preliminary model that aligns IS success variables with public sector characteristics as shown in Figure 1. The design of the model reflects the views expressed by participants (see above discussion) of each of the most highly ranked variables. The design of the model is therefore based on the following key arguments. It is argued 
that 'meeting user requirements', the highest ranked variable, reflects the user's expectation for 'system usability and performance' (e.g. ease of use) and 'information quality' (e.g. accuracy). In other words, without having access to a suitable system which provides the appropriate information, the user's needs are not met. These variables, together with 'user acceptance and IS ownership' (e.g. using systems without resistance) determine 'use'.

Use in turn enables public sector employees to be 'accountable' (e.g. to their ministers) and to exercise 'expenditure control' (e.g. over the budget). The emergence of the variable 'interaction with the IT infrastructure' of other government departments not only improves use (e.g. by providing the public with a whole of government service approach) but also 'meets long term needs'. As mentioned in an earlier section, the study by Adelakun and Jennex (2002) of IT executives, CIO's and IS managers revealed a similar finding, namely that success of an IS project is determined in a large part of how well the IS interacts within the organisational infrastructure.

\section{IS Success Variables}

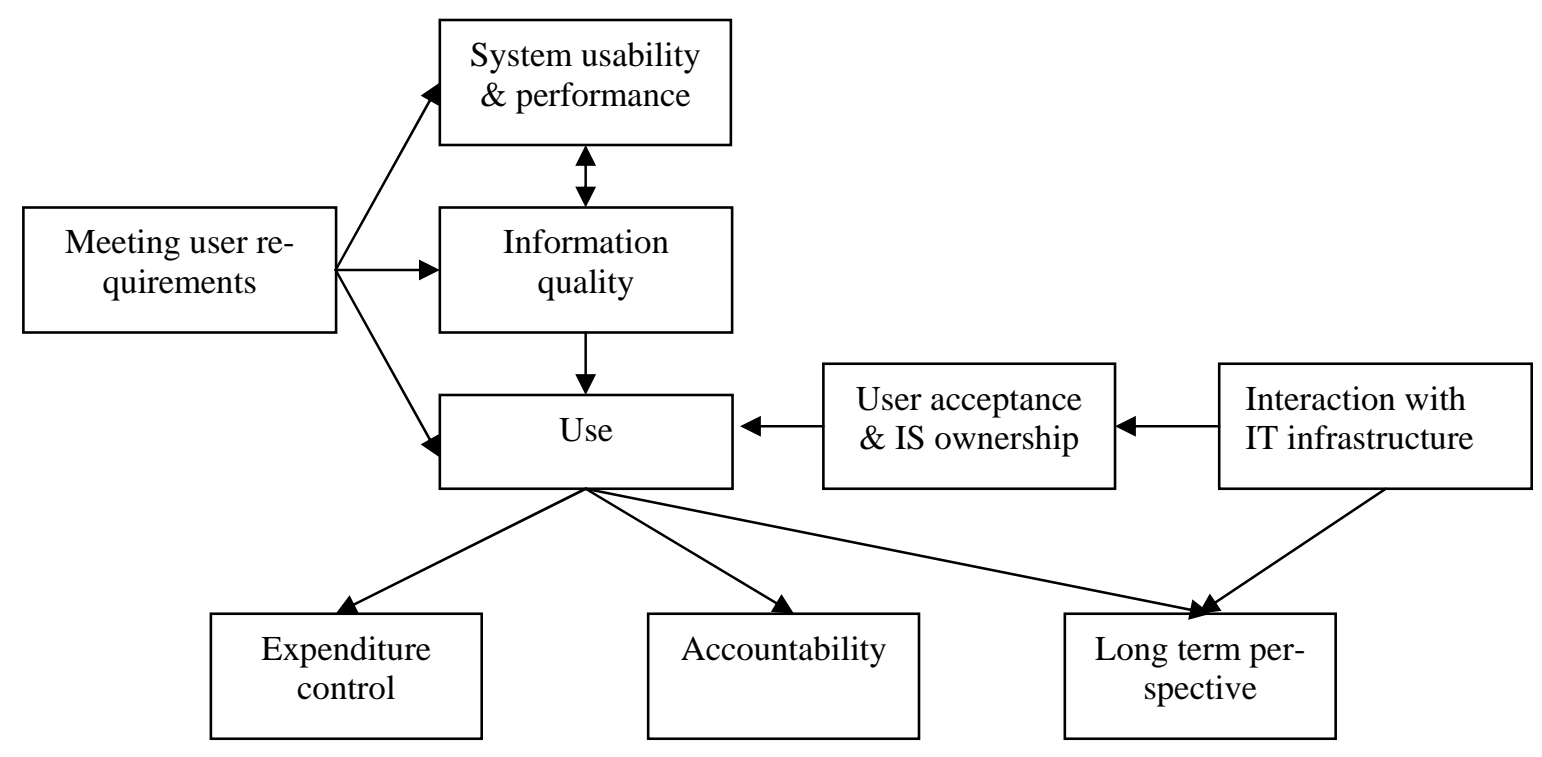

Public Sector Characteristics

Figure 1: Aligning WA Public Sector IS Success Variables and Characteristics

\section{Conclusion}

IS success is a topic widely researched as evident from the IS success models that have emerged over recent years and the well known perspectives that various stakeholders have on what they regard as successful IS. However, it has been recognized that research is under represented in the public services sector despite the importance of this sector. The sector is a major investor in IS and relies heavily on IS to stay efficient and effective. This study provides one of few attempts that have been made to explore the characteristics of the sector and to establish associated IS success factors.

When the study asked participants to identify IS success factors, a full range of variables were identified but after ranking the responses and taking into account the highest ranked ones the fol- 
lowing emerged: meeting user requirements, system usability and performance, information quality and use, user acceptance and IS ownership, and interactions with the rest of IT infrastructure. These findings differ from those shown in the IS success models reviewed earlier. Compared to that of DeLone and McLean (1992, 2003) and its respecified version (Seddon, 1997), the variables found to be used in assessing success by earlier IS were most prominent. In other words, they emphasised perspectives of the user, use and information quality. They did not emphasise the overall effect on the organization, except for interaction with the organisation's IT infrastructure. This could be a key difference between the two sectors, i.e. the need for the private sector to remain viable while such a concern is not highly visible in the public sector. It is recommended that further research be carried out in this respect.

In this study, the majority of participants from the Western Australian government agencies held the view that the public sector differs from the private sector. In particular they identified three key areas, namely accountability, expenditure control and taking a long term perspective that provides the differentiation. The proposed model shown in Figure 1 is an early attempt to link IS success variables with public sector characteristics. It needs, however, to be remembered that the model took into account only the three highest ranked IS variables which is a subjective decision. Using different approaches to interpreting the findings (e.g. taking further variables into account) will lead to different IS success models. The model, unlike the DeLone and McLean style models, takes into account organisational characteristics. In this way the approach resonates with those of Ballantine et al. (1998) and Hwang et al. (2000) who recognised environmental factors, and also with Seddon (1997) who recognized benefits to society.

The study took place in Western Australia and hence the findings and conclusions cannot be generalised across the entire publics sector. They represent the opinions of those stakeholders that participated in the study and relate to the particular types of IS on which they expressed their opinions. The findings, therefore, may be situational specific (see Flowers, 1996) and as such, the study should be regarded as an exploratory one but one which hopefully encourages other researchers to consider the public services sector in their endeavours.

\section{References}

Adelakun, O. \& Jennex, M. E. (2002). Stakeholder process approach to information systems evaluation. Eighth America's Conference on Information Systems, Dallas.

Al-Wohaibi, M., Masoud, F.A., \& Edwards, H.M. (2002). Fundamental risk factors in deploying IT/IS Projects in Omani government organisations. Journal of Global Information Management, 10(4), 1 - 22.

Australian Bureau of Statistics (1998). Australian social trends 1998. Retrieved 30 June 2004 from http://www.abs.gov.au

Ballantine, J., Bonner, M., \& Levy, M. (1998). Developing a 3-D model of information systems success. In E. J. Garrity \& G. L Sanders (Eds.). Information Systems Success Measurement. Hershey, PA: Idea Group Publishing.

Barki, H. \& Hartwick, J. (1989). Rethinking the concept of user involvement. MIS Quarterly, 13(1), 53-63.

Belassi, W., \& Tukel, O. (1996). A new framework for determining critical success/ failure factors in projects. Project Management, 14(3), 141-151.

Bloom, N. L. (1996). Select the right IS project manager for success. Personnel Journal, 75(1).

Briner, W., Hastings, C., \& Geddes, M. (1996). Project leadership (2nd ed.). Guildford: Biddles Ltd.

Campbell, W. (2003). How to survive in the public sector. CIO, 16(18), 1.

Crawford, P. (1996). The serious business of governing. RIPAA(NSW). Sydney: Hale and Iremonger. 
Davis, F. D. (1989). Perceived usefulness, perceived ease of use, and user acceptance of information technology. MIS Quarterly, 13(3), 319-340.

DeLone, W. H. \& McLean, E. R. (1992). Information systems success: The quest for the dependent variable. Information Systems Research, 3(1), 60-95.

DeLone, W. H. \& McLean, E. R. (2003). The DeLone and McLean model of information systems success: A ten-year update. Journal of Management Information Systems, 19(4), 9 - 30.

DeLooff, L. A. (1996). IS outsourcing by public sector organisation. International Federation for Information Processing.

Dowse, A. (2003). The benefits, limitations and governance implications of federated public sector systems. $14^{\text {th }}$ Australasian Conference on Information Systems, Perth.

Fisher, J. (2001). User satisfaction and system success: Considering the development team. Australian Journal of Information Systems, 9(1), 21 - 29.

Flowers, S. (1996). Software failure: management failure. West Sussex, UK: John Wiley \& Sons.

Garson, G. D. (1999). Handbook of public information systems. Retrieved 10 April 2005 from http://hcl.chass.ncsu.edu/garson/dekker.htm

Ginzberg, M. J. (1981). Early diagnosis of MIS implementation failure: Promising results and unanswered questions. Management Science, 27(4), 459-478.

Holloway, I. (1997). Basic concepts for qualitative research. Oxford: Blackwall Science.

Hwang, H. I. \& Thorn, R. G. (1999). The effect of user engagement on system success: A meta-analytical integration of research findings. Information \& Management, 35(4), 229 - 236.

Hwang, M. I., Windsor, J. C., \& Pryor, A. (2000). Building a knowledge base for MIS research: A metaanalysis of a systems success model. Information Resources Management Journal, 13 (2), 26 - 32.

Ives, B., Hamilton, S., \& Davis, G. B. (1980). A framework for research in computer-based management information systems. Management Science, 26(9), 910 - 934.

Kappleman, L. \& McLean, E. (1991). The respective roles of user participation and user involvement in the information system implementation success. ICIS Conference Proceedings, New York.

Marriott, I. (2002). Public sector: The search for quality and value for money. Gartner COM-17-5685.

Myers, M. D. (1997). Qualitative research in information systems. MIS Quarterly, 21(2), 241-242.

Saleem, N. (1996). An empirical test of the contingency approach to user participation in information systems development. Journal of Management Information Systems, 13(1), 145 - 166.

Seddon, P. B. (1997). A respecification and extension of the DeLone and McLean model of IS success. Information Systems Research, 8(3), 240- 253.

Seddon, P. B. \& Kiew, M. Y. (1996). A partial test and development of DeLone and McLean's model of IS success. Australian Journal of Information Systems, 4(1), 90-109.

Seneviratne, S. J. (1999). Is technological progress social progress? University of Southern California, Los Angeles.

Shenhar, A. J., Levy, O., \& Dvir, D. (1997). Mapping the dimensions of project success. Project Management Journal, 28(2), 5 - 13.

Staples, D. S., Wong, I., \& Seddon, P. B. (2002). Having expectations of information systems benefits that match received benefits: Does it really matter? Information \& Management, 40,115-131.

Szajna, B. \& Scamell, R. W. (1993). The effects of information system user expectations on their performance and perceptions. MIS Quarterly, 17(4), 493 - 514.

Travers, M. (2001). Qualitative research through case studies. California: Sage Publications. 
Walker, R. (1985). Applied qualitative research. England: Aldershot.

Wateridge, J. (1998). How can IS/IT projects be measured for success? International Journal of Project Management, 16(1), 59 - 63.

White, D. \& Fortune, J. (2002). Current practice in project management - An empirical study. International Journal of Project Management, January 20(1), 1-11.

Williams, A. H. (1998). The future of public sector management - The public interest. Retrieved 2 March 2005 from http://www.apsc.gov.au/media/williams200898.htm

Yin, R. K. (1994). Case study research: design and methods. Thousand Oaks, CA: Sage.

Yin, R. K. (2003). Applications of case study research. Thousand Oaks, CA: Sage.

Yin, K. R. (2003). Case study research design and methods. Thousand Oaks, CA: Sage.

\section{Biographies}

Ivana Elpez is currently working as a Co-ordinator of Corporate Systems within the Western Australian public sector. Prior to this role she has worked as a Programmer Analyst and a Business Systems Analyst. Ivana has completed a First Class Honours degree in Management Information Systems at Edith Cowan University.

Dr Dieter Fink is an Associate Professor and co-ordinator for the DBA in Information Systems in the School of Management Information Systems at Edith Cowan University in Perth, Western Australia. Prior to joining academe he worked as a Systems Engineer for IBM and as Manager, IS Consulting for Arthur Young (now Ernst \& Young). He has been a visiting academic at a number of universities: Australian National University, University of Cape Town, Canterbury University, and Free University of Berlin. His primary interest is in IT Governance which includes establishing and measuring the value of IT investments, IT adoption, and minimising the risk of ecommerce and e-business. Further details about him are provided at http://myprofile.cos.com/fink22 